Proc. Estonian Acad. Sci. Eng., 2003, 9, 2, 73-90

\title{
Directional and extreme wind properties in the Gulf of Finland
}

\author{
Tarmo Soomere and Sirje Keevallik
}

\begin{abstract}
Marine Systems Institute, Tallinn Technical University, Paldiski mnt. 1, 10137 Tallinn, Estonia; tarmo@phys.sea.ee, sirje.keevallik@ebs.ee

Received 14 February 2003, in revised form 4 April 2003

Abstract. The wind regime of the Gulf of Finland consists of SW and north winds dominating in the whole Baltic Sea basin and of local east and west winds blowing along the axis of the gulf. The angular structure of strong winds does not match the structure of all winds since they sometimes blow from directions where winds generally are infrequent. The 3-hour mean wind speed in the most severe south and SW storms, estimated on the basis of the Weibull distribution, is about $24 \mathrm{~m} / \mathrm{s}$ once in a century, thus by $2-3 \mathrm{~m} / \mathrm{s}$ less than in the Baltic Proper. The mean wind speed in the strongest east and north storms may reach $21-23 \mathrm{~m} / \mathrm{s}$ or $19-22 \mathrm{~m} / \mathrm{s}$ once in a century, respectively. The frequency and the maximum speed of east and north winds is relatively small in the eastern part of the gulf. SE winds are infrequent and weak.
\end{abstract}

Key words: wind climate, extreme wind speed, Baltic Sea meteorology, marine winds.

\section{INTRODUCTION}

A typical exercise in ocean engineering is to predict the dependence of the sea state on the wind parameters. In order to create a reliable picture of the properties of the sea state, it is necessary to use the complete wind statistics (wind climate), i.e., the joint two-dimensional probability distribution of the surface-level wind speed and direction combined with the distributions of their spatial and temporal behaviour over the whole area of interest.

The Baltic Sea is located within the west-wind zone where in the weather patterns mostly cyclones coming from the west or SW dominate. Local winds in the area in question are closely related to the cyclones and pressure gradients around these wind systems. During certain seasons, interplay of the North Atlantic Low (next to Iceland) and the Siberian High (that covers a huge domain in the northern part of the Eurasian continent) elucidates the prevalence of SW winds. 
Generally, the wind information derived from the atmospheric pressure data is more reliable for the analysis of relatively slow processes than the data from local measurements. The water body of the Baltic Sea has a strong impact on the local climate. Its extremely complex configuration results in a high variability and huge contrasts of surface-level winds $\left[{ }^{1}\right]$. The wind regime in the Baltic Proper is highly anisotropic. The direction of the strongest winds is drastically different from the prevailing direction of geostrophic winds $\left[{ }^{2-7}\right]$ and the properties of the geostrophic wind frequently do not match the features of surface-level winds. Moreover, wind regime estimates by contemporary local area atmospheric models such as HIRLAM have large systematic deviations from the actually measured wind data $\left[{ }^{8}\right]$. For that reason, the analysis below is restricted to the in situ measurements of the surface-level wind parameters.

According to numerous wind measurements on ships $\left[{ }^{1}\right], \mathrm{SW}$ winds dominate almost round the year at the open Baltic Sea. Only in March-April relatively weak north and NE winds prevail. Marine wind reconstructions based on coastal measurements mostly agree with this description $\left[{ }^{6}\right]$. The dominating wind direction is SW. A secondary maximum corresponds to north or NNW winds. This wind pattern is not necessarily permanent during October-February but is very stable during April-August. The directional distribution of the extreme wind speed also has two maxima corresponding to SW and north (occasionally NNW) winds, a deep minimum for easterly winds and a minor minimum for NW winds. The primary properties of the directional wind distributions (the prevailing winds, the frequency of their occurrence, the distributions of the mean, and the maximum wind speed) are nearly identical over the whole northern Baltic Proper $\left.{ }^{6}\right]$.

The wind anisotropy has a specific importance for the Baltic Sea. The strongly anisotropic local wind climate is one of the main factors forming the sea level and driving the associated coastal processes $\left[{ }^{9,10}\right]$. An analysis of the temporal variation of the connection between the Baltic Sea water level and the NAO index suggests that the regional atmospheric circulation occasionally differs from the large-scale one. The seasonal means of the local sea level apparently reflect the regional wind climate to a large extent. The Baltic Sea level can even be used for the identification of climatic changes in the region [ $\left.{ }^{9}\right]$.

An acute need for quantifying the directional structure of the surface-level open sea wind climate arises in various coastal engineering studies $\left[^{11,12}\right]$. Since an accurate description of the sea state is frequently critical in such studies, the correct description of the prevailing direction of strong winds and the maximum wind speed have enormous importance. The historical wave data apparently do not contain sufficient information about the open sea wave regime and, in particular, do not represent possible changes of the wind regime. The most feasible way to reconstruct the typical and extreme wave regimes at a specific site is numerical wave modelling that can be adequate only if it is based on the reliable open sea wind information.

The purpose of the current paper is to extend the analysis of the directional and extreme properties of the wind climate, established for the northern Baltic 
Proper in $\left[{ }^{6,7}\right]$, to the Gulf of Finland, the second largest sub-basin of the Baltic Sea. As different from the Baltic Proper that is roughly aligned along the prevailing wind direction, the axis of the Gulf of Finland is nearly perpendicular to this direction. However, the data from Kalbådagrund (Fig. 1) show that a substantial part of winds match this axis $\left.{ }^{13,14}\right]$. Thus the basic features of the wind regime in the surrounding mainland (e.g., the domination of the aerosol transport from SW to $\mathrm{NE}$ in the Estonian mainland $\left[{ }^{15}\right]$, the increase of the frequency of winds blowing from southern sectors and the decrease of the frequency of NE winds $\left[^{3}\right]$, or the changes in the local wind resulting from the alteration of geostrophic wind properties $\left.\left[{ }^{16}\right]\right)$ not necessarily become evident in the Gulf of Finland. Moreover, the difference of the wind speed at open sea and in the coastal area strongly depends on the wind direction $\left[{ }^{13,14}\right]$.

Owing to the deficit of open sea wind data, the properties of marine wind in the gulf are estimated mostly on the basis of coastal measurements. Although the measurement sites are located close to the coast, many of them exhibit wind properties of the transient zone or even those of the continental wind climate. The data sets and their ability to capture the open sea wind properties are discussed in Section 2.

The wind measurements on ships suggest that SW winds dominate in the Gulf of Finland round the year $\left[{ }^{1}\right]$. Only during late winter and spring (March-May) eastern winds may prevail. This sketch harmonizes neither with the data from many coastal measurement sites nor from Kalbådagrund $\left[{ }^{13,14}\right]$. The disagreement is evidently caused by a large variation of wind properties in different parts of the gulf. The Gulf of Finland is narrow, surrounded by mainland except in its westmost area and strongly elongated in the east-west direction. Its length is about

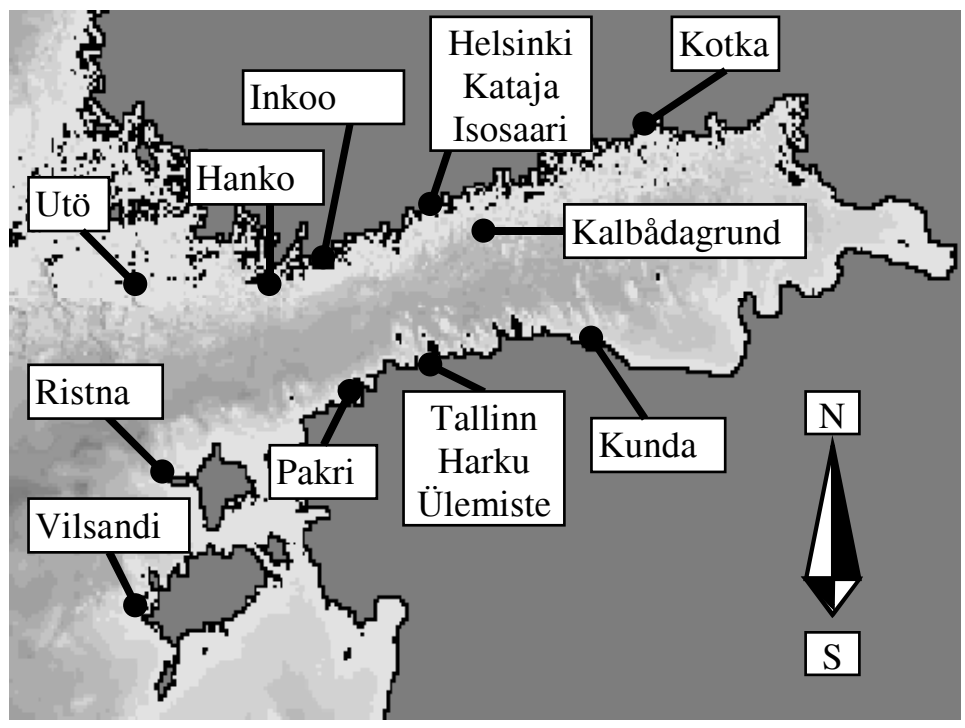

Fig. 1. Location of measurement sites in the vicinity of the Gulf of Finland. 
$400 \mathrm{~km}$ and its width varies between 48 and $135 \mathrm{~km}$. The western part of the gulf apparently is influenced by winds prevailing in the Baltic Proper and the eastern part is entirely surrounded by the mainland. Thus the contrasts of wind regimes in different parts of the gulf are likely. In Section 3 an attempt is made to identify the variation of the wind climate of the gulf.

The directional distributions of several mean and extreme wind parameters are constructed in Section 4 with the use of the Weibull distribution technique. Section 5 contains a discussion of the distinguishing features of the established wind climate and the contrasts of this climate in different areas of the Gulf of Finland.

\section{DATA SETS AND BASIC WIND PROPERTIES}

The analysis is mostly based on data from routine meteorological measurements at a standard height of $10 \mathrm{~m}$ at eight weather stations in the coastal zone of the Gulf of Finland. Utö, Hanko, Inkoo, Helsinki (Kataja and Isosaari), and Kotka measurement sites are located at the northern coast and Pakri, Tallinn (Ülemiste and Harku), and Kunda at the southern coast of the gulf (Fig. 1). Among the sites, Utö is located virtually in the Baltic Proper and together with Vilsandi (known to represent adequately open sea wind properties $\left[{ }^{3,7}\right]$ ) it serves as a reference for wind properties in the Baltic Proper. The results are compared with wind properties at Kalbådagrund (measured at a height of $32 \mathrm{~m}$ in the central area of the gulf) that are described in $\left.{ }^{13,14}\right]$.

The wind speed and direction has been filed at all sites eight times per day as an average over a certain time interval ( 2 or $10 \mathrm{~min}$ ) at every three hours starting from $0.00 \mathrm{GMT}$ with the resolution of $1 \mathrm{~m} / \mathrm{s}$. The angular resolution at the Finnish sites is formally $10^{\circ}$ (36 directions) but it has been less, at least during certain time intervals, and the data are only partially homogeneous. The angular resolution at the Estonian sites was $22.5^{\circ}$ (16 directions) until about 1976, and $10^{\circ}$ afterwards. A few records with an angular resolution of $5^{\circ}$ were considered erroneous.

The change of the angular resolution occurred due to the replacement of the measurement devices in the middle of the 1970s. It was accompanied by an increase of the measurement interval from $2 \mathrm{~min}$ to $10 \mathrm{~min}$. An analysis of the directional wind structure in different years shows that the change insignificantly influenced the accuracy of defining the wind direction. The older routine lead to a certain overestimation of the maximum wind speed, to a relatively large dispersion of wind speeds, and to a certain roughness of the distribution of the wind speeds. However, no systematic overestimation of the wind speed occurred and we do not distinguish the older part of the time series. Owing to that reason, in the following the angular resolution $22.5^{\circ}$ is mostly used except in a few cases of shorter time series that evidently are homogeneous.

The total length of the analysed times series at Utö, Hanko, Inkoo, Kotka, Pakri, and Kunda (Table 1) is 35-40 years that generally is considered long enough to make climatological conclusions. The measurements at the other sites 
Table 1. Main parameters of the time series

\begin{tabular}{|c|c|c|c|c|c|c|c|c|c|c|c|}
\hline \multirow[t]{3}{*}{ Site } & \multirow[t]{3}{*}{ Years } & \multicolumn{6}{|c|}{ Number of recordings } & \multirow{3}{*}{$\begin{array}{c}\text { Mean } \\
\text { wind } \\
\text { speed, } \\
\mathrm{m} / \mathrm{s}\end{array}$} & & \multirow[t]{3}{*}{ b } & \multirow{3}{*}{$\begin{array}{c}\text { Daily } \\
\text { varia- } \\
\text { tion, } \\
\%\end{array}$} \\
\hline & & \multirow[t]{2}{*}{ Total } & \multirow{2}{*}{$\begin{array}{c}\text { Erro- } \\
\text { neous or } \\
\text { absent }\end{array}$} & \multicolumn{4}{|c|}{ Wind speed, $\mathrm{m} / \mathrm{s}$} & & & & \\
\hline & & & & Calm & $>5$ & $>10$ & $>=15$ & & & & \\
\hline Utö & & 119064 & 0 & & & & & 6.65 & 2.03 & 7.51 & 5.5 \\
\hline Hanko & & 1 & 0 & & & & & 6.03 & 2.02 & & 5.4 \\
\hline Inkoo & & 114200 & 14354 & & 45481 & 7745 & 1255 & 5.71 & 1.91 & 6.44 & 10.7 \\
\hline Isosaari & 1984-2001 & 49672 & 1972 & 919 & 2797 & 5924 & 1011 & 6.56 & 2.03 & 7.40 & 6.4 \\
\hline Kataja & 1961-1984 & 6939 & 35 & 580 & 3860 & 7018 & 1032 & 6.33 & 2.09 & 7.15 & 9.5 \\
\hline Kotka & $1961-2001$ & 119064 & 261 & 1230 & 440 & 6483 & 864 & 5.09 & 1.78 & 5.72 & 6.8 \\
\hline Kunda & $1966-2$ & 10226 & 53 & & 284 & & & 4.30 & 1.66 & 4.81 & 20.2 \\
\hline Ülemiste & 1966 & & 6 & & 135 & 0 & 70 & 4.51 & 1.83 & 5.08 & 28.1 \\
\hline & & & & & & & 2 & 3.62 & 1.96 & 4.09 & 30.2 \\
\hline & & 102256 & & 2122 & 32861 & 3957 & 751 & 4.66 & 1.55 & 5.18 & 16.0 \\
\hline Vilsandi & 1969-1999 & 89616 & 21999 & 356 & 35456 & 7708 & 1473 & 6.29 & 1.90 & 7.09 & 7.2 \\
\hline
\end{tabular}

have been performed during 15-25 years. The number of recordings even in the shortest series exceeds 40000 . The overall formal data quality (characterized by the number of erroneous or absent measurements) is mostly excellent except at Inkoo where about $10 \%$ of the data is missing. A part of the recordings in the Vilsandi time series (1977-1991) was not available in digital form.

An implicit possibility to judge whether a specific site represents only local winds or the wind regime in a wider area consists in comparing the statistical parameters of the measured wind data with the typical ones for the area in question. A standard method to estimate the wind parameters is based on the Weibull (Gnedenko) distribution $\left[{ }^{17}\right]$. It has the probability density function

$$
f(u)=k u^{k-1} b^{-k} \exp \left[-(u / b)^{k}\right],
$$

where $u>0$ is the instantaneous wind speed and $k$ is the scale parameter. In North-European climate $k \approx 2.0\left[{ }^{2}\right]$ and the wind speed distribution is close to a special case of the Weibull distribution with $k=2$.

Practically $k \approx 2.0 \pm 10 \%$ at all the sites located at the northern coast of the gulf (Table 1). Thus their data evidently represent well the basic features of the wind regime in the Baltic Sea basin. At Pakri and Kunda the parameter $k$ differs for 17 to $23 \%$ from its typical value. Winds at these sites apparently are affected by some local features. Indeed, e.g., the Kunda site is sheltered from the southern direction by a $30-40 \mathrm{~m}$ high cliff that is located at a distance of about $1 \mathrm{~km}$.

The accuracy of a reconstruction of the marine wind regime is particularly sensitive with respect to the mainland-caused distortions in the coastal data. This feature implies a specific data inspection additionally to routine quality check procedures. Unfortunately, no unambiguous criterion exists to select the maritime wind regime. Since wind speed generally greatly decreases in the transient zone, 
a small difference between the mean wind speed at open sea and at a particular site indicates that the site eventually represents well the maritime wind. Another typical feature of maritime winds is that the wind speed has much lower daily variation (a few per cent) at open sea than at the continental wind areas (typically, tens of per cent). A characteristic feature of the maritime wind regime in the Baltic Proper, the Bothnian Sea, and the Gulf of Finland is that the directional distributions of frequencies of all winds, moderate and strong winds as well as the distributions of the mean and the maximum wind speed are qualitatively similar $\left[{ }^{6,13}\right]$. This feature will be discussed in the next section.

The mean wind speed at open sea in the northern Baltic Proper is estimated in [ $\left.{ }^{1}\right]$ as 14 knots $(7.2 \mathrm{~m} / \mathrm{s})$. The wind speed at Utö $(6.7 \mathrm{~m} / \mathrm{s})$ is by $7 \%$ and at Vilsandi by $12 \%$ less than at open sea (Table 1 ). The small rate of the wind speed reduction shows that these sites evidently represent marine winds adequately $\left[{ }^{6,7}\right]$.

The mean wind speed is $7.2 \mathrm{~m} / \mathrm{s}$ also in the western part of the Gulf of Finland. It decreases in the eastern direction and is $6.2 \mathrm{~m} / \mathrm{s}$ in the eastern part of the gulf $\left[{ }^{1}\right]$. These estimates agree well with the data from Kalbådagrund where the mean wind speed (reduced to the $10 \mathrm{~m}$ level) is about $7 \mathrm{~m} / \mathrm{s}\left[{ }^{13,14}\right]$. The mean wind speed at Hanko is about $15 \%$ and at Kataja about $10 \%$ less than the wind speed at open sea (Table 1), thus these sites apparently are located in marine wind conditions. The mean wind speed at Isosaari insignificantly differs from that at open sea. A probable reason is that measurements at Isosaari were started in 1984 and they partially depict the overall increase of wind speed during the last decades. Since the mean wind speed at Inkoo is more than $20 \%$ smaller than at open sea, apparently Inkoo is located in the transient zone.

In the eastern part of the gulf, the mean wind speed is by $1 \mathrm{~m} / \mathrm{s}$ less than in the western part. The decrease is evident both at open sea and at the coasts. The mean wind speed at Kotka is about $15 \%$ less than the open sea wind speed showing that this site apparently is located in the marine wind area. The relatively low values of the mean wind speed at the southern coast of the gulf (Table 1) suggest that the sites there probably do not represent open sea wind. Kunda site apparently is located in the transient zone. Pakri and Ülemiste evidently belong to the transient or even continental wind regime, because the mean wind speed at these sites is about 30\% less than at open sea. The recorded wind speeds at Harku are uncommonly low for the marine environment.

An analysis of the typical daily variation of the wind speed supports this grouping (Fig. 2, Table 1). This variation is less than $10 \%$ at all the sites at the northern coast of the gulf and is particularly small (5-7\%) at Vilsandi, Utö, Hanko, Isosaari, and Kotka. It is about $10 \%$ at Kataja and Inkoo, showing that the coast reasonably affects winds at these sites. The sites at the southern coast exhibit a relatively large daily variation (16-30\%) confirming that they represent either the transient (Pakri) or continental wind regime. 


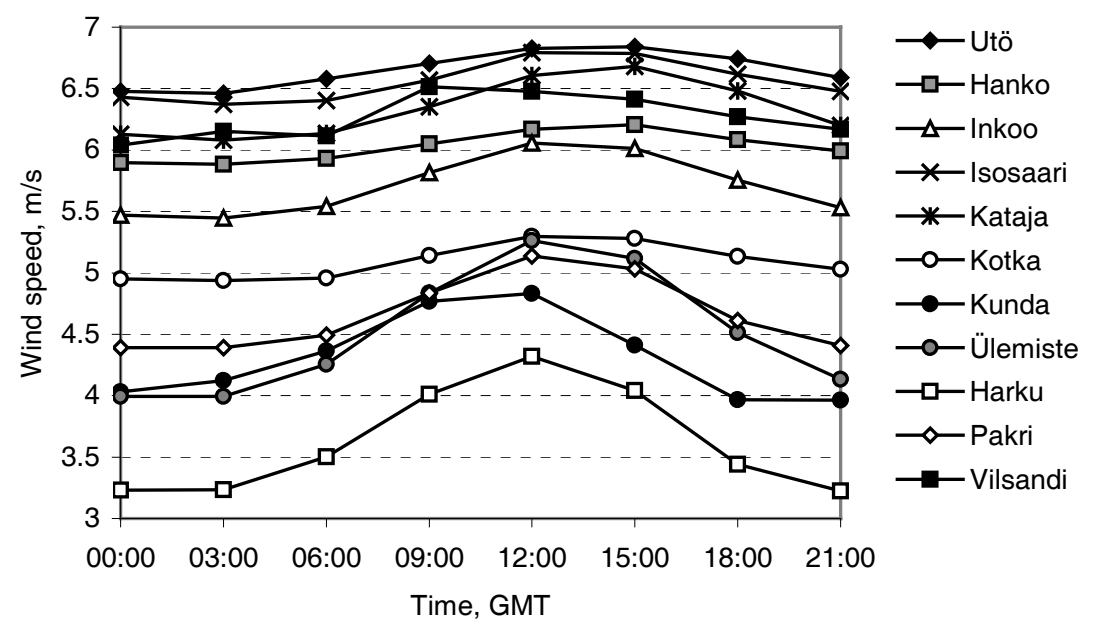

Fig. 2. Daily variation of the mean wind speed at measurement sites.

\section{DIRECTIONAL DISTRIBUTIONS OF WIND PARAMETERS}

The directional distribution of winds in the Baltic Proper has a two-peaked shape that is particularly spectacular in the case of moderate and strong winds and exists during all seasons $\left[{ }^{6}\right]$. An extremely high peak corresponds to dominating SW winds and a somewhat lower peak - to north or NNW winds. A deep minimum represents the low frequency of easterly winds (Fig. 3). The contrasts between the frequencies of occurrence of winds $>5 \mathrm{~m} / \mathrm{s}$ from different directions may be as high as 10 times. The directional distribution of all winds matches well the distribution of moderate and strong winds.
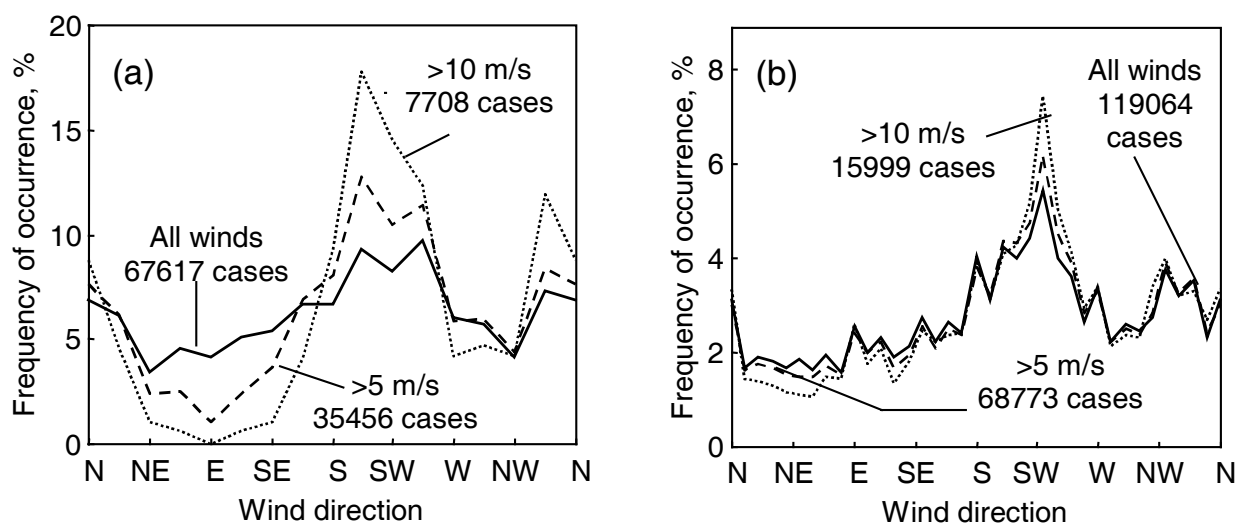

Fig. 3. Directional distribution of winds: (a) at Vilsandi 1966-1999, with angular resolution of $22.5^{\circ}$; (b) at Utö 1961-2001, with angular resolution of $10^{\circ}$. 
The directional wind distribution at Utö contains a minor maximum for east winds (Fig. 3). It apparently reflects winds formed in the Gulf of Finland. A number of small peaks evidently reflect the non-homogeneity of the directional resolution of the time series. The directional distributions of all winds, moderate, and strong winds practically coincide showing that the Utö wind regime is truly maritime. It is yet unclear if the separation of the secondary maximum for northern winds into two peaks corresponding to NW and north winds is a local feature of the Utö site or represents the actual wind pattern in the northernmost part of the Baltic Proper.

The prevailing wind directions in the Baltic Proper do not match the axis of the Gulf of Finland. The gulf is aligned roughly perpendicular to the SW and SSW winds that prevail in the Estonian mainland. The Kalbådagrund data (recorded at a lighthouse located at open sea in the central part of the gulf) shows that a large portion of winds nevertheless is aligned along the gulf axis $\left[^{13,14}\right]$. However, this feature may represent specific wind properties in the narrow central part of the gulf. The wind regime in its western part evidently is affected by winds formed in the Baltic Proper. Axis-oriented winds may be less frequent and intense compared to SW and north winds in the relatively wide eastern part of the gulf.

The wind regime in the western part of the Gulf of Finland evidently is well represented in the Hanko data and should become to some extent evident in the Pakri data (Fig. 4). The directional distributions of all winds and winds $>5 \mathrm{~m} / \mathrm{s}$ well match each other at Hanko. They all have three well-defined maxima of comparable height. The main maximum corresponds to SW winds. It has the same location as in the Utö data but is much wider. Its southern sub-peak may be caused by the influence of the Estonian mainland and islands that deviate SW winds to the left to some extent. Another sub-peak corresponding to west winds may be associated with winds blowing along the axis of the gulf. However, both sub-peaks may simply represent the non-homogeneity of the data.
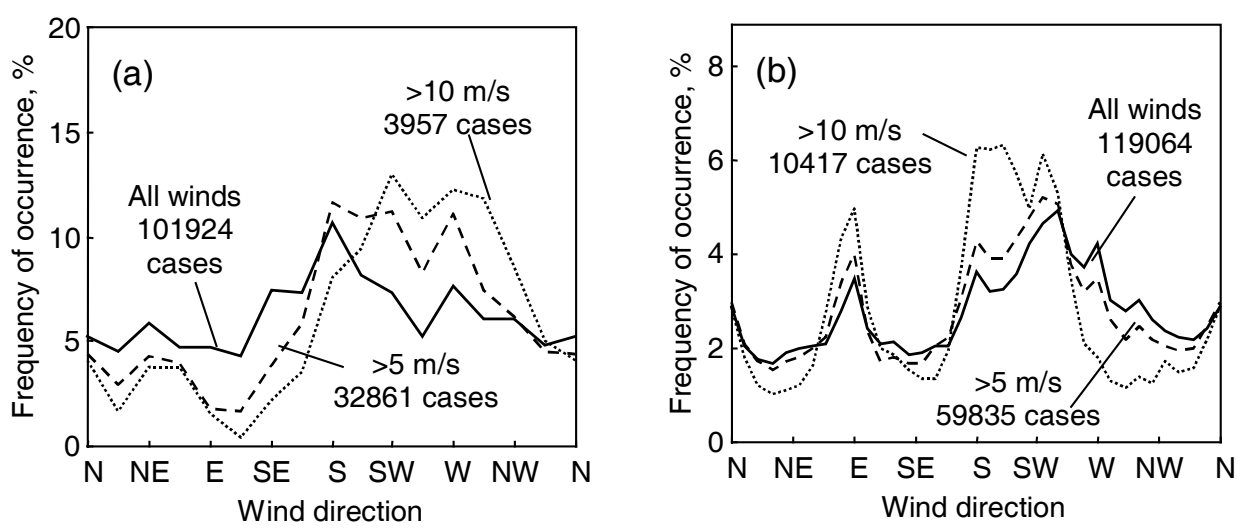

Fig. 4. Directional distribution of winds: (a) at Pakri 1966-2000, with angular resolution of $22.5^{\circ}$; (b) at Hanko 1961-2001, with angular resolution of $10^{\circ}$. 
The secondary maxima at Hanko correspond to north and east winds. Both the frequency and intensity of east winds is comparable to those of SW winds. A comparison with the Kalbådagrund data suggests that east winds blow exactly along the axis of the gulf, mostly during the spring and summer seasons $\left[{ }^{13,14}\right]$. The frequency of north winds at Hanko is clearly less than in the Baltic Proper whereas the quota of east winds exceeds about two times that at Utö. The Finnish mainland apparently causes the deep minimum for NW and NNW winds at Hanko instead of a secondary maximum at Utö. The differences in the wind patterns at these sites become evident in the distributions of moderate and strong winds.

The directional wind distribution at Pakri qualitatively coincides with that at Hanko. It also has a wide maximum for SW winds combined with a secondary maximum for relatively frequent and strong ENE winds. A minor peak for north winds is hardly distinguishable from the one for ENE winds. SE winds are infrequent and weak at both sites. Another common feature of these sites is that the most probable direction of strong winds clearly differs from that for all winds. Strong winds mainly blow from SW or west at the southern coast of the gulf and from south to SW at the northern coast.

The wind regime in the central area of the gulf apparently is well represented by the Kataja and Isosaari data (Fig. 5). They mostly agree well with each other and with the data from Kalbådagrund $\left[{ }^{13,14}\right]$. Both the directional distribution of all winds and the distribution of winds $>5 \mathrm{~m} / \mathrm{s}$ have a wide major maximum corresponding to WSW winds and contain a secondary peak for south winds. Well-defined minor peaks show relatively high frequency and intensity of east winds at both sites. Another minor peak for north winds is evident at Kataja but hardly visible at Isosaari.

The data from the neighbourhood of Tallinn (Ülemiste and Harku) are not easy to interpret. The sites are located at a distance of about $3 \mathrm{~km}$ from the shoreline, on the top of the North-Estonian cliff at a considerable distance from other buildings, about $10 \mathrm{~km}$ from each other. The above has shown that the wind regime at these sites definitely is not maritime. The secondary maxima for strong and moderate ENE winds at Ülemiste and Harku yet may represent the high frequency of these winds at open sea. Since the directional wind distributions at Harku are qualitatively different from those in all other sites in question, local features evidently play a great role at this site. The wind field at Harku may be affected by urban winds that have a tendency to blow towards the city centre $\left[{ }^{18}\right]$.

A general feature of the wind regime in the central part of the gulf is that the frequency of north and NW winds is lower than in its westmost part, in particular, among strong winds. The intensity of east winds is also less than at Hanko where east winds were particularly evident among strong winds (Fig. 4). The prevailing directions of strong winds coincide with those in the westmost part of the gulf but again do not match the prevailing direction of all winds. The wide peak for strong SW winds at Isosaari results from plotting data in Fig. 5d 

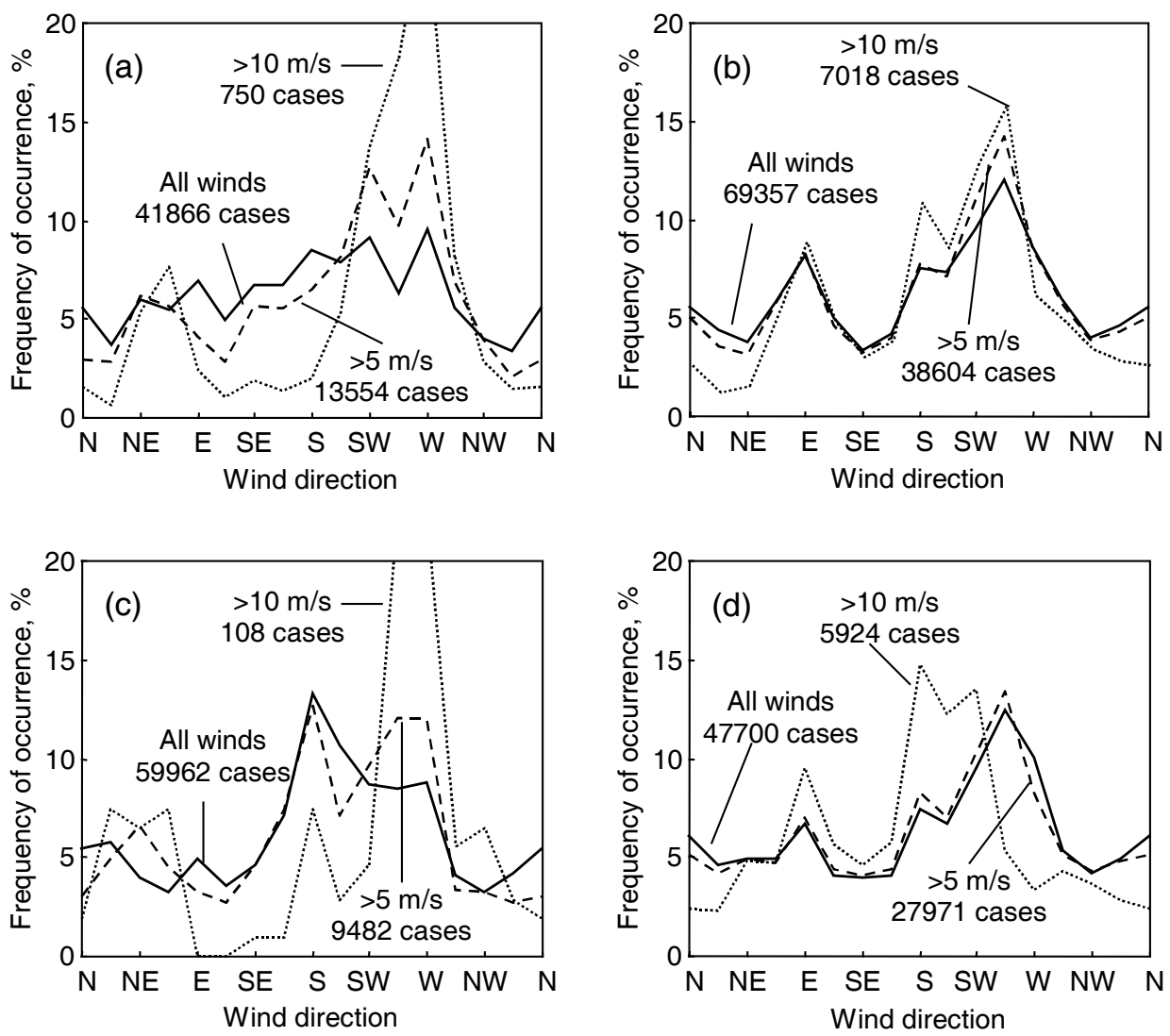

Fig. 5. Directional distribution of winds: (a) at Tallinn-Ülemiste 1966-1980; (b) at Helsinki-Kataja 1961-1984; (c) at Tallinn-Harku 1980-2000; (d) at Helsinki-Isosaari 1984-2001. Angular resolution is $22.5^{\circ}$.

with angular resolution of $22.5^{\circ}$ and does not become evident with a resolution of $10^{\circ}$ (Fig. 6). This detail shows that directional wind distributions occasionally are rather sensitive to the angular resolution of the recording and averaging procedures.

In the eastern part of the Gulf of Finland, the most appropriate data to represent the marine wind regime are those from Kotka. The directional distributions of all wind categories are qualitatively similar. They consist of three maxima whereas the main one actually comprises two peaks (Fig. 7). The major maximum corresponds to south, SW and WSW winds, and contains a larger portion of these winds than in the other parts of the gulf. A large role of south winds apparently reflects the relatively large width of the eastern part of the gulf. The secondary maxima corresponding to east and north winds are lower than in the central part of the gulf. 


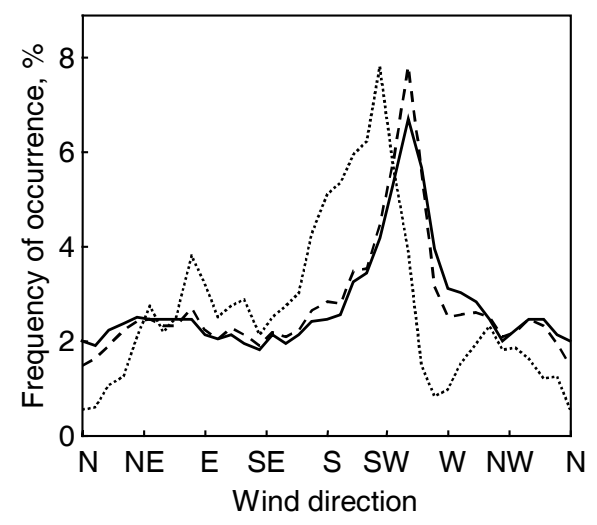

Fig. 6. Directional distribution of winds at Helsinki-Isosaari 1984-2001. Angular resolution is $10^{\circ}$.
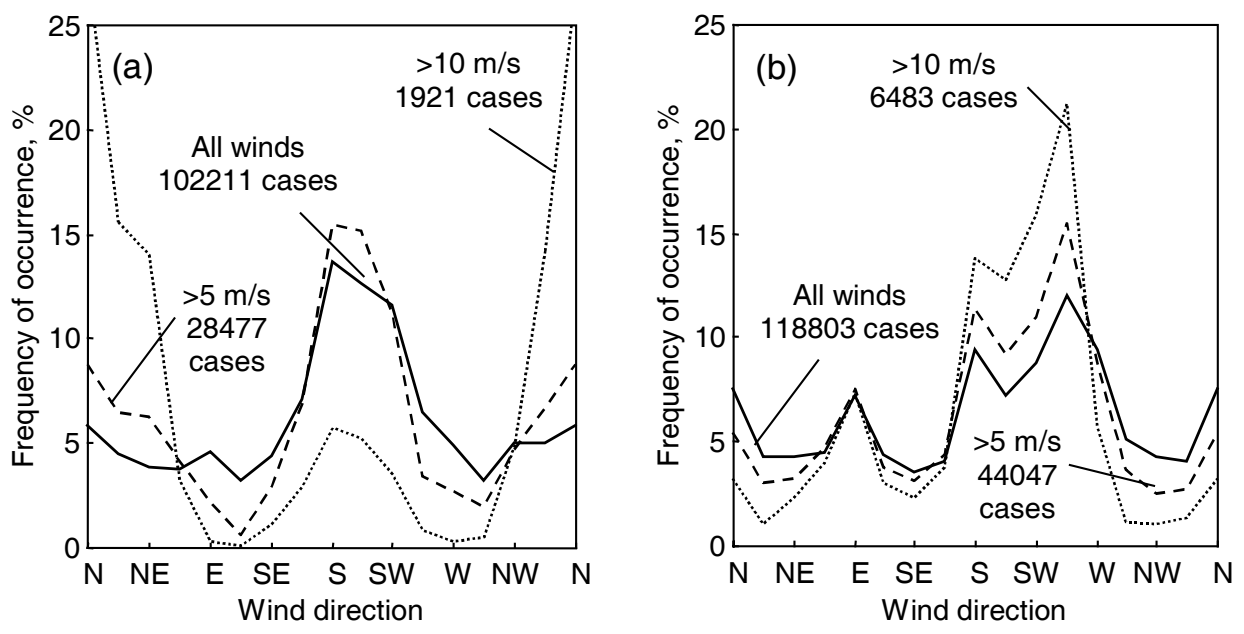

Fig. 7. Directional distribution of winds: (a) at Kunda 1966-2000; (b) at Kotka 1961-2000. Angular resolution is $22.5^{\circ}$.

At the southern coast, the majority of winds blow from south or SW like in the other parts of the gulf. A minor maximum corresponding to east winds is poorly visible in the Kunda data. Another secondary peak for north winds only becomes evident among moderate and strong winds. The prevalence of north winds among strong winds at Kunda is evidently caused jointly by a small number of registered strong winds and by the fact that this site is fully open only to the northern direction. The above has shown that a high cliff southwards from Kunda may distort the maritime wind pattern. However, the peak for north winds apparently is reliable because the results of the HIRLAM model well matched the measured north wind data whereas the agreement for other directions was rather poor $\left[{ }^{8}\right]$. 


\section{ANGULAR DISTRIBUTIONS OF EXTREME WIND PARAMETERS}

The maximum wind speed in the area in question may reach $35-40 \mathrm{~m} / \mathrm{s}\left[{ }^{19,20}\right]$. These values, however, mostly represent wind speed in short and local gusts. For many applications, in particular, for wind wave studies, they are irrelevant, because the sea state represents the behaviour of the wind in large sea areas during many hours. Extreme wave heights at open sea are determined not by the maximum wind speed but by the duration and spatial extent of extreme wind events. The saturation time of wave heights in the Baltic proper is $6-8 \mathrm{~h}\left[{ }^{21}\right]$. Thus extreme wave loads can be only computed on the basis of the distribution of wind speed in storms lasting, at least, for several hours.

Storms with the mean wind speed exceeding $25 \mathrm{~m} / \mathrm{s}$ during a longer time interval occur seldom even in the Baltic Proper. The wind speed exceeding as low a threshold as $22 \mathrm{~m} / \mathrm{s}$ was recorded only five times during 1977-1991 at Vilsandi. Statistically, storms with the 6-hour mean wind speed reaching $25 \mathrm{~m} / \mathrm{s}$ are expected to occur once in a decade in the northern Baltic Proper. Once in 20 (100) years the 6-hour mean wind speed may reach $\left.26 \mathrm{~m} / \mathrm{s}(28 \mathrm{~m} / \mathrm{s}){ }^{7}\right]$.

The relatively small size of the Gulf of Finland and the essential decrease of the mean wind speed in the eastern direction suggest that extreme wind speeds in the gulf are lower than in the Baltic Proper. Strong storms that have 10-minute wind speeds over $20 \mathrm{~m} / \mathrm{s}$ are relatively infrequent in the Bothnian Sea and the Gulf of Finland $\left[{ }^{13}\right]$. Although the frequency of strong winds $(>10 \mathrm{~m})$ in the Gulf of Finland practically coincides with that in the Baltic Proper $\left[{ }^{7}\right]$, the frequency of winds $>15 \mathrm{~m} / \mathrm{s}$ in the gulf is about twice less than in the Baltic Proper (1.5\% and $2-4 \%$, respectively $\left.\left[{ }^{1}\right]\right)$. This property combined with the observations in $\left[{ }^{13,14}\right]$ suggests that the probability of very strong storms (wind speed $>20 \mathrm{~m} / \mathrm{s}$ ) in the Gulf of Finland is modest and that the maximum wind speed in such storms is less than in the Baltic Proper.

The established directional properties of the marine wind regime did not include any quantitative estimates of wind speeds. The above has shown that the difference between the mean wind speed at open sea and at the coast varies for $7-20 \%$ at different sites. This difference alone demonstrates that it is virtually impossible to use a unique algorithm for reconstructing marine winds on the basis of coastal data. From the analysis in $\left.{ }^{13,14}\right]$ it follows that the wind speed over the open sea and that in the coastal area (both simultaneously measured at locations well representing maritime wind regime) may differ for $40-100 \%$. The difference depends on the wind direction and generally is smaller for winds blowing from the open sea. However, the difference decreases when the wind speed increases. In strong storms the wind speed at open sea and in the coastal zone virtually coincide (and the wind speed at the coast may even exceed that at open sea $\left[{ }^{22}\right]$ ). This quality allows to reconstruct extreme marine wind regimes on the basis of coastal data. 
The standard meteorological data traditionally are interpreted as representing mean wind conditions during a much longer time interval. The recorded maximum wind speed (Fig. 8) is rather sensitive relative to short-time wind fluctuations owing to the small aspect ratio of the wind speed integration time (10 min) and the measurement interval (3-6 hours). This is particularly true for the directional distribution of extreme wind speeds. For example, the strongest $\mathrm{NE}$ wind at Kunda during 35 years $(20 \mathrm{~m} / \mathrm{s})$ was filed in 1968 . The next strongest wind from this direction $(18 \mathrm{~m} / \mathrm{s})$ was recorded once in 1967 and twice in 1968. The strongest NE wind starting from 1982 (i.e., after implementing the new measurement routine) has been only $17 \mathrm{~m} / \mathrm{s}$.

The maximum wind speed occurring during a longer time interval can be estimated using approximate theoretical distributions of the frequency of occurrence $f(u)$ of different wind speeds. The probability that wind speed does not exceed $U$ is

$$
P(u<U)=F(U), \quad f(u)=F^{\prime}(U), \quad \int_{0}^{\infty} F(U) \mathrm{d} U=1 .
$$

Let us interpret a recorded wind speed at a measurement instant $T_{0}$ as the mean wind speed during the time interval $\left[T_{0}-\frac{1}{2} T, T_{0}+\frac{1}{2} T\right]$. Here $T$ is the measurement interval. Then a particular wind speed $U^{*}$ probably does not occur during a time interval containing $N$ hours if $P\left(u<U^{*}\right)<T / N$. An estimate for the wind speed that occurs once during $N$ hours is defined as $P\left(u<U^{*}\right)=T / N$.

A widely used approximation for the distribution of wind speeds is the Weibull distribution $\left[{ }^{17}\right]$. (Notice that this distribution is not a universal tool for describing all wind properties. For example, the wind speed in gusts can be frequently better described by the gamma distribution $\left.\left[{ }^{13}\right]\right)$. Its parameters for the measurement sites are given in Table 1 and a selection of estimates of the 3-hour
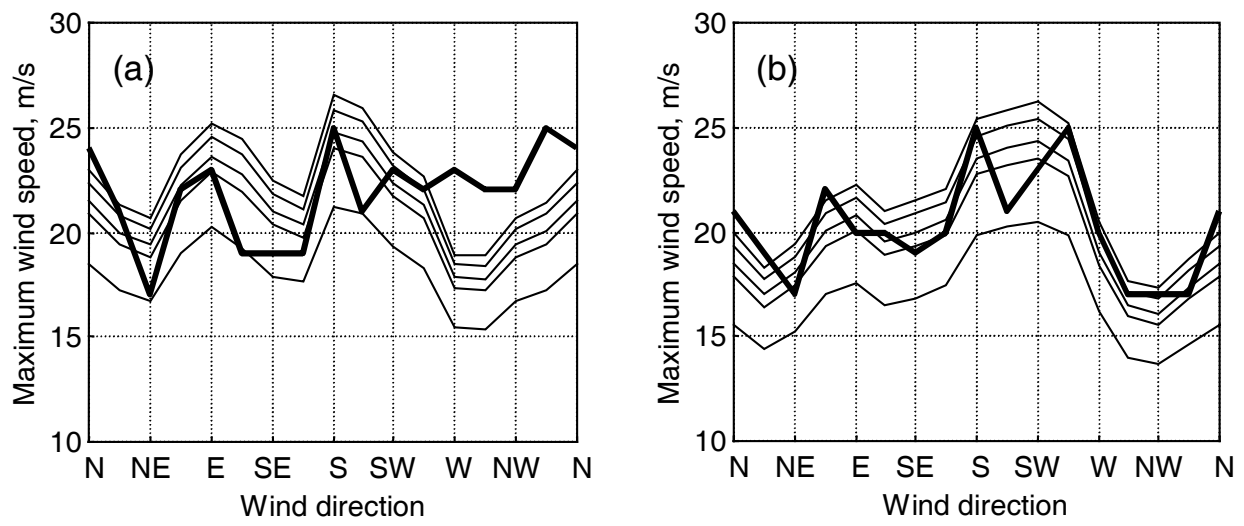

Fig. 8. Directional distribution of the estimated maximum of the 3-hour mean wind speed once in $1,10,20,50$, and 100 years (thin curves from the bottom to the top, respectively) and the maximum recorded wind speed (bold curve): (a) at Hanko 1961-2001; (b) at Kotka 1961-2000. 
maximum wind speed occurring once during 1-100 years is given in Table 2. The most reliable are the estimates based on the Hanko and Kotka data, because these sites represent adequately marine wind conditions and the time series are relatively long. An overestimation of extreme wind speeds based on Isosaari data apparently represents the increase of the mean wind speed during the last decades $\left[{ }^{23}\right]$. Also, the time series at Isosaari is about two times shorter than at the other sites and, strictly speaking, the statistical estimates made on its basis are not directly comparable with those obtained for the other sites. The parameters of the Weibull distribution available for Kalbådagrund $\left[{ }^{13}\right]$ are based only on a few years of wind data and cannot be used for climatological conclusions.

It is interesting to notice that the estimates of the extreme wind speed based on the Hanko and Kotka data agree perfectly although the parameters of the Weibull distribution for these sites differ considerably (Table 1). This coincidence suggests that, as different from the mean wind speed, the wind speeds in extreme storms are comparable in the whole Gulf of Finland and generally do not decrease in the eastern direction. A comparison of these results with those obtained at Utö suggests that the highest wind speeds in the gulf area are comparable with those in the open Baltic Sea and occur in the proximity of the Baltic Proper. However, the extreme wind speed in the inner area of the gulf is by $2-3 \mathrm{~m} / \mathrm{s}$ less than in the open Baltic Sea. This conclusion agrees well with the results of high-resolution wind measurements at Ristinina Cape. Although the maximum of the 10-minute wind speed during the extreme NNW storm in November 2001 exceeded $27 \mathrm{~m} / \mathrm{s}$, the maximum of 6-hour mean wind speed was about $23 \mathrm{~m} / \mathrm{s}$ (according to T. Tomson, Estonian Energy Research Institute at Tallinn Technical University, private communication).

Estimates of the directional distribution of extreme wind speeds are less reliable, because winds from a particular direction form a small fracture of the total data. Another subtle problem is the stability of the wind direction. Its possible variations during strong storms may result in a systematic error of such estimates for specific directions. Thus the results described below in this section should be interpreted only as indicative.

The most trustworthy are again the estimates based on the data from Hanko and Kotka (Fig. 8). The directional distributions of the estimated and recorded maximum wind speeds agree particularly well at Kotka (except that the recorded maximum values for the WSW and SW directions are unusually low). Notice that these distributions qualitatively coincide with the directional wind distributions

Table 2. Maximum 3-hour mean wind speeds ( $\mathrm{m} / \mathrm{s}$ ) occurring once during different time periods

\begin{tabular}{l|c|c|c|c|c}
\hline \multirow{1}{*}{ Site } & \multicolumn{5}{c}{ Duration of the time period, years } \\
\cline { 2 - 6 } & 1 & 10 & 20 & 50 & 100 \\
\hline Utö & 20.9 & 23.7 & 24.5 & 25.4 & 26.2 \\
Hanko & 19.0 & 21.5 & 22.3 & 23.2 & 23.8 \\
Isosaari & 19.7 & 22.6 & 23.4 & 24.4 & 25.1 \\
Kotka & 18.4 & 21.2 & 22.0 & 23.1 & 23.8
\end{tabular}



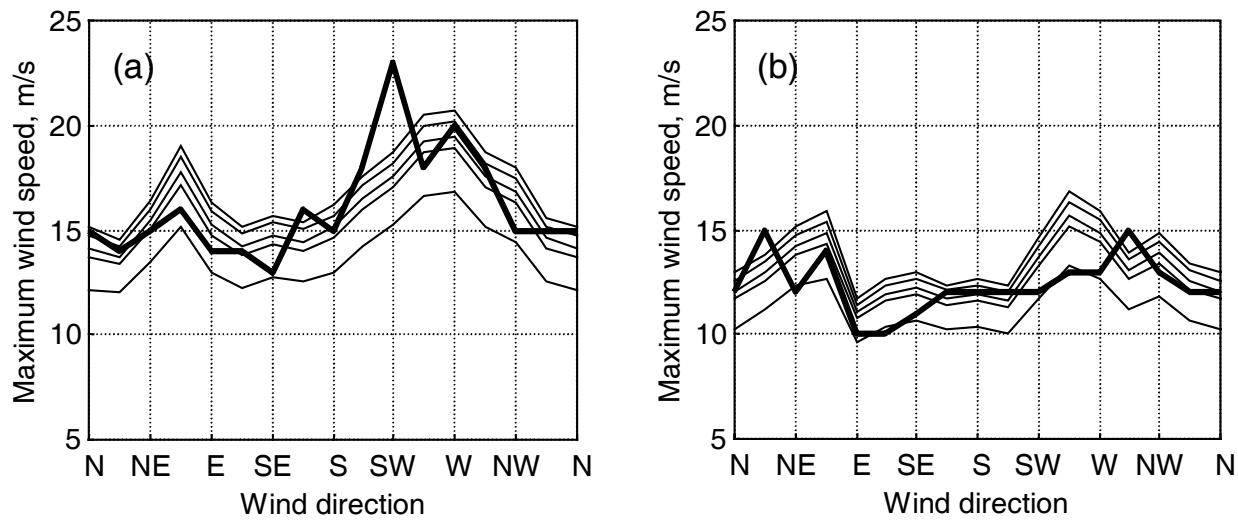

Fig. 9. Directional distribution of the estimated maximum of the 3-hour mean wind speed once in $1,10,20,50$, and 100 years (thin curves from the bottom to the top, respectively) and the maximum recorded wind speed (bold curve): (a) at Ülemiste 1966-1980; (b) at Harku 1980-2000.

in Fig. 4. All these distributions mostly agree also at Hanko except for the west and NW winds where the match is rather poor. The relatively high recorded maximum wind speed for those directions apparently do not adequately represent the statistical features of the wind field.

The most severe winds at both sites are expected to blow from south (Hanko) or south to SW (Kotka). Their speed apparently is overestimated by $5-10 \%$ (Table 2) and the 3-hour mean wind speed should not exceed $24 \mathrm{~m} / \mathrm{s}$ once in a century. East storms are the second strongest. The maximum 3-hour mean wind speed in east storms once in a century may reach $21 \mathrm{~m} / \mathrm{s}$ in the eastern part of the gulf and $23 \mathrm{~m} / \mathrm{s}$ in its western part. North winds may have a speed of 19-20 m/s in the eastern part of the gulf and $21-22 \mathrm{~m} / \mathrm{s}$ in the western part (the higher wind speeds may occur at open sea and in the southern part of the gulf because of the sheltering effect of Finland). The 3-hour mean wind speed of NE and SE winds should not exceed $17-18 \mathrm{~m} / \mathrm{s}$ once in a century.

The data from the southern coast (Fig. 9) do not represent the actual values of the extreme wind speed at open sea. They capture the strongest SW winds as well as relatively strong east or ENE winds. The 3-hour mean wind speed in NE storms may reach $18-19 \mathrm{~m} / \mathrm{s}$ once in a century according to Ülemiste data. The data from Harku evidently cannot be used for reconstructions of extreme properties of the open sea wind. Yet it might be possible to reconstruct open sea winds using the recently reanalysed data from the island of Naissaar $\left[{ }^{24}\right]$.

\section{DISCUSSION}

The wind regime of the Gulf of Finland is formed as a superposition of SW and north winds dominating in the whole Baltic Sea basin, and local winds blowing 
along the axis of the gulf. As a result, directional distributions of wind properties contain numerous maxima and minima. SW winds are the most frequent but not necessarily the strongest. East winds also occur frequently and, as different from the wind patterns in the Baltic Proper, may be nearly as strong as SW winds. West winds are less frequent. North winds play an important role only at the southern coast of the gulf. NNW and NW winds (that are relatively frequent and the strongest in the northern Baltic Proper $\left.{ }^{7}\right]$ ) are unimportant in the inner parts of the gulf. A particular property of the wind regime of the whole Gulf of Finland area is that SE winds are infrequent and weak. This feature is clearly evident in all data sets but does not exclude the possibility of dominating of relatively weak SE winds during a certain season, e.g., in March-May as shown in [ $\left.{ }^{1}\right]$.

The wind structure shows a certain variance within the gulf area. At the northern coast of the gulf, moderate $(6-10 \mathrm{~m} / \mathrm{s})$ and strong $(>10 \mathrm{~m} / \mathrm{s})$ winds mostly come from south or SW. At the southern coast, they mainly blow from SW or west. The relative frequency and intensity of both east winds (NE or ENE winds at the southern coast) and north winds (NNW winds in the westernmost part of the gulf) decrease in the eastern direction. The wind regime at a particular site (except at the SE coast of the gulf) could evidently be well characterized by parameters describing this decay.

This picture has been mostly constructed based on wind measurements at the northern coast of the gulf. The measurement sites at the southern coast probably do not adequately represent marine wind properties. The Estonian mainland and large islands shelter this coast from the prevailing SW winds. Local features, in particular, the North-Estonian Cliff, may additionally modify wind fields near the southern coast of the gulf.

The high frequency and speed of winds blowing along the axis of the gulf is evidently caused by its particular geometry. The wind patterns probably encounter specific boundary-layer effects, e.g., low-level jets that may play a decisive role in wind energy in some areas $\left[{ }^{25}\right]$. The relatively large portion of east winds and their high speed is a specific feature of the gulf that does not become evident in the Baltic Proper and is rather uncorrelated with the directional distribution of the geostrophic wind. The coinciding shape of highly anisotropic directional wind distributions at radically separated measurement sites suggests that spatially homogeneous storms blowing along the gulf axis may occur frequently. Such events may excite particularly high waves since changes in the wind direction during severe storms generally lead to fast decrease of the wave heights $\left[{ }^{26}\right]$.

An interesting feature of the wind regime is that the directional distribution of strong winds not necessarily matches this distribution for all winds. Statistically, the majority of winds blow from SW or west but strong winds $(>10 \mathrm{~m} / \mathrm{s})$ mostly come either from south or SSW. This feature suggests that the traditional wind roses do not adequately describe the wind regime. The mismatch apparently results from the orientation of the gulf that does not match the dominating wind directions. Local winds frequently follow the shape of the gulf but very strong storms, covering large areas, do not. An example is the extreme NNW storm in 
November 2001 that had the maximum 6-hour mean wind speed about $23 \mathrm{~m} / \mathrm{s}$ in the western part of the gulf. Statistically, such a storm should never occur during the whole history of the Gulf of Finland.

The mean wind speed in the most severe storms in the Gulf of Finland is by $2-3 \mathrm{~m} / \mathrm{s}$ less than in the Baltic Proper. The directional distribution of extreme wind speeds qualitatively coincides with the distribution of the frequency of winds. South or SW winds apparently are the strongest whereas the 3-hour mean wind speed may reach $24 \mathrm{~m} / \mathrm{s}$ once in a century. East winds are confined to a very narrow direction span but are the second strongest. Their maximum wind speed may reach $21-23 \mathrm{~m} / \mathrm{s}$ once in a century in different parts of the gulf. North winds may have the 3-hour wind speed of 19-22 m/s. NE and SE winds should not exceed $17-18 \mathrm{~m} / \mathrm{s}$ once in a century.

\section{ACKNOWLEDGEMENTS}

This study was mostly performed in the framework of classification of wind regimes in coastal waters of Estonia when the first author was employed by the Estonian Marine Institute. The research was partially financed by the Estonian Environmental Investment Centre (Contract L39-01) and by the Estonian Science Foundation (grant No.4025). The authors are deeply grateful to the Finnish Meteorological Institute (Contract 67/410/01) for presenting the wind data from the northern coast of the Gulf of Finland.

\section{REFERENCES}

1. Mietus, M. (coordinator) The Climate of the Baltic Sea Basin, Marine Meteorology and Related Oceanographic Activities. Report No. 41. World Meteorological Organisation, Geneva, 1998.

2. Troen, I. and Petersen, E. L. European Wind Atlas. Risø National Laboratory, Roskilde, Denmark, 1989.

3. Kull, A. and Meitern, H. Changes in wind climate. In Country Case Studies on Climate Change Impacts and Adaptation Assessments in the Republic of Estonia (Tarand, A. and Kallaste, T., eds.). Stockholm Environment Institute, Tallinn Centre, Tallinn, 1998, 23-25.

4. Kull, A. Estonian wind climate and wind resources. In Estonia. Geographical Studies (Punning, J.-M., ed.). Estonian Academy Publishers, Tallinn, 1996, $29-42$.

5. Kull, A. Eesti tuuleatlas. Tartu University, Tartu, 1996.

6. Soomere, T. and Keevallik, S. Anisotropy of moderate and strong winds in the Baltic Proper. Proc. Estonian Acad. Sci. Eng., 2001, 7, 35-49.

7. Soomere, T. Extreme wind speeds and spatially uniform wind events in the Baltic Proper. Proc. Estonian Acad. Sci. Eng., 2001, 7, 195-211.

8. Ansper, I. and Fortelius, C. HIRLAM-mudeli tuuleprognoosi hindamine Läänemerel. Publicationes Instituti Geographici Universitas Tartuensis, 2003, 93, 195-205.

9. Andersson, H. C. Influence of long-term regional and large-scale atmospheric circulation on the Baltic Sea level. Tellus, 2002, 54, 76-88.

10. Hellemaa, P. The Development of Coastal Dunes and their Vegetation in Finland. Academic Dissertation. University of Helsinki, Department of Geography, 1998. 
11. Elken, J., Kask, J., Kõuts, T., Liiv, U., Perens, R., and Soomere, T. Hydrodynamical and geological investigations of possible deep harbour sites in north-western Saaremaa Island: Overview and conclusions. Proc. Estonian Acad. Sci. Eng., 2001, 7, 85-98.

12. Soomere, T., Elken, J., Kask, J., Keevallik, S., Kõuts, T., Metsaveer, J., and Peterson, P. Laevaliikluse purustav mõju Viimsi poolsaare, Aegna ja Naissaare randadele ning selle neutraliseerimise võimalused. Research report. Marine Systems Institute, Tallinn Technical University, Tallinn, 2002.

13. Launiainen, J. and Laurila, T. Marine wind characteristics in the northern Baltic Sea. Finnish Mar. Res., 1984, 250, 52-86.

14. Launiainen, J. and Saarinen, J. Examples of comparison of wind and air-sea interaction characteristics on the open sea and in the coastal areas of the Gulf of Finland. Geophysica, $1982,19,33-46$.

15. Russak, V. Atmospheric aerosol variability in Estonia calculated from solar radiation measurements. Tellus, 1996, 48A, 786-791.

16. Keevallik, S. and Rajasalu, R. Winds on the $500 \mathrm{hPa}$ isobaric level over Estonia (1953-1998). Phys. Chem. Earth, 2001, 26, 425-429.

17. Conradsen, K. and Nielsen, L. B. Review of Weibull statistics of estimation of wind speed distribution. J. Climate Appl. Meteorol., 1984, 23, 1173-1183.

18. Fernando, H. J. S., Lee, S. M., Anderson, J., Princevac, M., Pardyjak, E., and CrossmannClarke, S. Urban fluid mechanics. Environ. Fluid Mech., 2001, 1, 107-164.

19. Handbook of Climate of the USSR, Vol. 4: Estonian SSR, Part 3: Wind. Gidrometeoizdat, Leningrad, 1966 (in Russian).

20. Prilipko, G. I. (ed.) Climate of Tallinn. Gidrometeoizdat, Leningrad, 1982 (in Russian).

21. Soomere, T. Wave regimes and anomalies off north-western Saaremaa Island. Proc. Estonian Acad. Sci. Eng., 2001, 7, 157-173.

22. Coastal Engineering Manual 2002. Department of the Army. U.S. Army Corps of Engineers. Manual No. 1110-2-1100 (CD).

23. Alexandersson, H., Schmith, T., Iden, K., and Tuomenvirta, H. Long-term trend variations of the storm climate over NW Europe. Global Atmosph. Ocean Syst., 1998, 6, 97-120.

24. Keevallik, S. Tallinna lahe tuuled. Publicationes Instituti Geographici Universitas Tartuensis, 2003, 93, 215-224.

25. Smedman, A-S., Högström, U., and Bergström, H. Low level jets - a decisive factor for offshore wind energy siting in the Baltic sea. Wind Eng., 1996, 20, 137-147.

26. Komen, G. J., Cavaleri, L., Donelan, M., Hasselmann, K., Hasselmann, S., and Janssen, P. A. E. M. Dynamics and Modelling of Ocean Waves. Cambridge University Press, Cambridge, 1994.

\section{Tuule suund ja ekstreemne kiirus Soome lahel}

\section{Tarmo Soomere ja Sirje Keevallik}

On näidatud, et Soome lahel kombineeruvad kaks tuulesüsteemi: Läänemere piirkonnas domineerivad edela- ja põhjatuuled ning piki lahe telge puhuvad idaja läänetuuled. Tugevate tuulte jaotus ilmakaarte järgi erineb summaarsest tuulte jaotusest. Tugevaim tuul puhub sageli suunast, kust tuult esineb üldiselt harva. Weibulli jaotuse abil arvutatud kolme tunni keskmine tuule kiirus võib tugevaimate lõuna- ja edelatormide ajal olla kuni $24 \mathrm{~m} / \mathrm{s}$ üks kord sajandis, see on $2-3 \mathrm{~m} / \mathrm{s}$ võrra väiksem kui Läänemere avaosas. Tuule kiirus piki lahe telge puhuvates idatormides võib olla kuni $23 \mathrm{~m} / \mathrm{s}$ (lahe idaosas kuni $21 \mathrm{~m} / \mathrm{s}$ ) ning põhjatormides kuni $22 \mathrm{~m} / \mathrm{s}$. Kagutuuled on suhteliselt harvad ja nõrgad. 